\title{
Early parental causal language input predicts children's later causal verb understanding
}

\author{
Aslı AKTAN-ERCIYES ${ }^{1 \star(D)}$ and Tilbe GÖKSUN ${ }^{2}$ (D) \\ ${ }^{1}$ Kadir Has University, Turkey \\ ${ }^{2}$ Koç University, Turkey \\ ${ }^{\star}$ Corresponding author: Aslı Aktan Erciyes, Kadir Has University, Istanbul 34083, Turkey. Email: asli.erciyes@ \\ khas.edu.tr
}

(Received 28 January 2021; revised 8 July 2021; accepted 18 November 2021

\begin{abstract}
How does parental causal input relate to children's later comprehension of causal verbs? Causal constructions in verbs differ across languages. Turkish has both lexical and morphological causatives. We asked whether (1) parental causal language input varied for different types of play (guided vs. free play), (2) early parental causal language input predicted children's causal verb understanding. Twenty-nine infants participated at three timepoints. Parents used lexical causatives more than morphological ones for guided-play for both timepoints, but for free-play, the same difference was only found at Time 2. For Time 3, children were tested on a verb comprehension and a vocabulary task. Morphological causative input, but not lexical causative input, during free-play predicted children's causal verb comprehension. For guided-play, the same relation did not hold. Findings suggest a role of specific types of causal input on children's understanding of causal verbs that are received in certain play contexts.
\end{abstract}

Keywords: causal language; causal input; play types; causal verb comprehension

\section{Introduction}

Causal reasoning emerges as early as 6 months of age for a wide variety of events such as physical causes of launching and entraining (e.g., Gopnik, Glymour, Sobel, Schulz, Kushnir \& Danks, 2004; Michotte, 1963; Piaget, 1954; Saxe \& Carey, 2006). Children's first verbs, however, are rarely used in causal structures before 4 years of age in naturalistic settings and even later in experimental settings (e.g., Bowerman, 1974; Göksun, HirshPasek \& Golinkoff, 2010; Kanero, Hirsh-Pasek \& Golinkoff, 2015; Muentener \& Lakusta, 2011). Most languages have at least one way to express causativity. In these causal events, an agent (e.g., figure) acts upon the patient (e.g., direct object) to change the state or position of the patient. Causal constructions in verbs can differ across languages. For example, languages use lexical or morphological verb constructions to express causativity (Comrie, 1989). Turkish has both lexical (e.g., kes, 'to cut') and morphological causatives (e.g., ye-Dir, 'make someone eat') to represent causativity. Only a few studies investigated

(C) The Author(s), 2021. Published by Cambridge University Press. This is an Open Access article, distributed under the terms of the Creative Commons Attribution licence (http://creativecommons.org/licenses/by/4.0), which permits unrestricted re-use, distribution and reproduction, provided the original article is properly cited. 
how parents' use of different causal constructions relates to children's use of causal language (e.g., Evers-Vermeul \& Sanders, 2001; van Veen, 2011). Different contexts may elicit different amounts of specific language structures (i.e., spatial language elicited in block play) (e.g., Ferrara, Hirsh-Pasek, Newcombe, Golinkoff \& Lam, 2011). The effects of differential input in these contexts on later child language outcomes are studied even less often. In the present study, we ask whether (1) parental causal language input differs for different types of play, and (2) early parental causal language input predicts children's later causal verb understanding.

\section{Parental language input and different types of play}

Parent-child play provides children with extensive verbal and nonverbal communication opportunities (Bornstein, Vibbert, Tal \& O’Donnell, 1992; Tamis-LeMonda \& Bornstein, 1991). Research suggests that specific parental input supports children's acquisition of specific word types such as adjectives (Blackwell, 2005), verbs (Naigles \& Hoff-Ginsberg, 1998), and spatial words (Levine, Ratliff, Huttenlocher \& Cannon, 2012). Less is known about how different play types elicit specific language input. The present study focuses on two types of play: (1) guided play and (2) free play. In guided play, adults scaffold children's exploration in achieving a goal (Fisher, Hirsh-Pasek, Golinkoff, Singer \& Berk, 2011; Weisberg, Hirsh-Pasek \& Golinkoff, 2013a). On the other hand, in free play, the child acts upon the environment and updates the information without having a specific goal (Piaget, 1954).

Parental language input at playtimes may depend on several factors, such as toys being used. For instance, parents used simpler language during toy play compared to when they engaged in book play (a catalog of toys and children's clothes was used) or toyless free play (Lewis \& Gregory, 1987). Additionally, parents produced more directives (e.g., put, lift) and longer utterances during toy play. The toyless free play elicited more repetitive language and fewer directives. Likewise, O'Brien and Nagle (1987) investigated parental language during parent-child play with different types of toys, such as dolls, vehicles, and shape sorters. Results showed that parents tended to talk the most while playing with dolls and talk the least while playing with vehicles. For specific types of input, Thippana, Elliott, Gehman, Libertus and Libertus (2020) examined how parental math talk differs for math-related (e.g., card games, puzzles, board games) vs. non-math-related activities (e.g., dolls, cars, kitchen/food). More math talk was elicited for math-related activities. Research also suggests that playing with spatial toys such as blocks increases parental spatial language input (Brosnan, 1998; Caldera, Culp, O’Brien, Truglio, Alvarez \& Huston, 1999; Ginsburg, 2007). While playing with blocks, parents direct children's attention to spatial relations between them (i.e., one block is under the other). Differences in input also occur when electronic toys are compared to traditional ones. For instance, Zosh, Hopkins, Jensen, Liu, Neale, Hirsh-Pasek, Solis and Whitebread (2017) found that traditional shape sorters elicited more spatial language from parents compared to electronic shape sorters. These findings indicate that specific toys might elicit specific language input. However, the context of play might also play a role while playing with specific toys.

Play contexts might alter adult language input at home (Eason \& Ramani, 2020; Zosh et al., 2017) as well as in educational settings (Weisberg et al., 2013a; Weisberg, Zosh, Hirsh-Pasek \& Golinkoff, 2013b; Weisberg, Kittredge, Hirsh-Pasek, Golinkoff \& Klahr, 2015). Parents produce specific types of input in certain play contexts. For 
example, playing with blocks may take different forms, depending on the type of play. Ferrara et al. (2011) investigated the use of spatial language during block play in three conditions: free play, guided play, or play with preassembled structures. Parents in the guided play condition, where the task was to reassemble a certain layout (e.g., build garage or helipad), used more spatial language (e.g., spatial locations, dimensions, spatial features) than parents in the free play or play with preassembled structures conditions. Parents had a goal to accomplish in a guided play context. Play contexts may also be influential for parent-child math talk. Eason and Ramani (2020) found that guided play elicited more math talk about fractions than unguided play for 4- and 5 -year olds.

Overall, research suggests that types of toys and play contexts may both influence how parents talk during play. The present study investigated parents' use of causal language in free play and guided play contexts to highlight the role of different play types in acquiring specific language structures.

\section{Parental causal input and children's causal verb understanding}

Early parental input is crucial for children's later language skills. Children's vocabulary development is closely related to the amount of exposure to different word types as well as the number of words (e.g., Hart \& Risley, 1995; Hoff, 2006). Exposure to different words predicts vocabulary development (Weizman \& Snow, 2001). Studies found interrelations among language input during parent-child play and children's language development (Bornstein, Vibbert, Tal \& O’Donnell, 1992; Tamis-LeMonda \& Bornstein, 1991; TamisLeMonda, Bornstein \& Baumwell, 2001). That is, the sophistication of parent-child play and parental language input enhances children's language outcomes.

Previous findings indicate that specific language skills that children acquire are related to specific parental input. For instance, parents' use of spatial language is related to children's spatial word knowledge (Cartmill, Pruden, Levine, GoldinMeadow \& Center, 2010; Kısa, Aktan-Erciyes, Turan \& Göksun, 2019; Pruden, Levine \& Huttenlocher, 2011). In their study on causality, McCabe and Peterson (1997) highlighted that children's causal language can be enriched by parental responses to children's questions as repeating, modifying, or responding to them. In a longitudinal study, they investigated the effects of parental language on children's causal language use and found that parents scaffolded children's causal language (e.g., using the connector because) by using why-questions. Likewise, for German and English, van Veen, Evers-Vermeul, Sanders and van den Bergh (2013) found a similar pattern in which parents adapted their causal connective use to children's increasing abilities. Growth curve analyses of children's imitated, elicited, and independent use of English because and German weil showed that parents scaffolded their children's causal connective use in elicited forms, using why/warum-questions. Although these studies indicate that parental causal language input might improve children's causal language, they are restricted only to the use of causal connectors and do not involve causal verbs. Our study will focus on causal connectives and different forms of causal verbs (lexical and morphological).

An accumulating body of evidence suggests that children hearing verbs in a variety of syntactic environments are at an advantage since each syntactic frame (e.g., with a direct object such as the duck is blicking the bunny, or in a sentence complement I like blicking) provides additional presumptions about that verb (e.g., Gleitman, 1990; Naigles, 1996; 
Naigles \& Hoff-Ginsberg, 1998). Therefore, in investigating children's comprehension of causal verbs, more sophisticated input analysis is needed. Corpus studies address parental input and children's use of causal connectors but not specifically target causal verbs (Evers-Vermeul, 2005; van Veen et al., 2013; but see You, Daum \& Stoll, 2020). As comprehension mostly precedes production, studying causal verb comprehension might be more informative. Taken together, children's causal language might be closely related to the quality of parental input received.

Children extract verb meanings making use of the syntactic and morphological cues available in the language (Gleitman, 1990; Landau \& Gleitman, 1985; Naigles, Gleitman \& Gleitman, 1993). Findings with 2- and 3-year-olds indicate that children become faster at processing grammatical devices like word order as they grow (Candan, Küntay, Yeh, Cheung, Wagner \& Naigles, 2012; Ilgaz \& Hirsh-Pasek, 2012). For instance, children are faster in processing word order if their language has a strict word order (e.g., English) than children who learn languages with flexible word order (e.g., Turkish and Mandarin). Thus, the type of input affects the speed of processing for grammatical elements. On the other hand, for lexical causatives, children have to rely on word order (in languages such as English and Turkish) as well as on the number of arguments or case marking (languages like Turkish) to extract causal information. In agglutinative languages such as Turkish, in addition to the word order, children use both nominal case marking and verbal morphology as cues to highlight the semantic information (Göksun, Küntay \& Naigles, 2008).

In Turkish, morphological causatives are formed by the attachment of a causative suffix (e.g., -Dır,, $t, I t-I r,-A r,-A r t)$, to either a transitive or intransitive verb stem (e.g., yap-tır, 'make [s.o.] do [s.t.]') (Göksel \& Kerslake, 2005). These causative suffixes attached to the verb stem are also predictable. Monosyllabic stems, most of which are intransitive, take one of these forms: $-I t,-I r,-A r$ or -Art. Polysyllabic stems that end with a vowel are combined with - $t$. The rest of the verb stems take the suffix -DIr. To give an example, the verb $u y u$ in Turkish refers 'to sleep' in English. When a causative suffix $-t$ is attached to the verb $u y u$, the new verb becomes $u y u$ - $t$ which refers 'to make someone sleep.' These suffixes act as a cue for young learners (Kornfilt, 1997). Although in language production, lexical causatives seem to emerge as early as 1 year of age (e.g., at 'throw'), morphological causatives (e.g., giy-Dir, 'make someone dress') do not appear before the age of 1;9 (Ketrez, 1999). The acquisition of different causatives in childhood has not been studied often in Turkish. For Turkish, causative morphemes might be one of the most salient cues that indicate semantic causativity. Since morphological marker is a transparent indicator of causality, which lexical causatives lack, morphological causatives might guide children to better extract information regarding causality. On the other hand, in the case of lexical causatives, children can only rely on the number of arguments and word order, which can be indicators of transitive structure. However, the flexible word order in Turkish cannot be informative at all times. Additionally, not all transitive verbs represent causality (Shibatani \& Pardeshi, 2002), and causal inferences based on word order might not yield correct outcomes. The verb-semantics hypothesis indicates that verbs might suggest less vs. more transparent causation that reflects the semantics of those verbs (Shibatani \& Pardeshi, 2002). If cause and effect are more independent of one another, more transparent causatives will be used. In those contexts where causality needs to be emphasized strongly, more causal input might be produced. Guided play provides such a context where parents assist their children for actions that involve more causal input to reach a goal (i.e., put the piece of the puzzle, turn the block) than a free play context. 


\section{The present study}

The present study extends the literature by examining early parental causal input (causal connectors, lexical and morphological causal verbs) for different play contexts (guided play and free play) and its relations with children's later causal verb understanding. The study had three timepoints. At Time 1 and Time 2, when children were 14 and 19 months of age, respectively, we used different play contexts (free play and guided play) to elicit parental language input. At Time 3, when children were 35 months of age, we administered a verb comprehension task (for both causal and non-causal verbs) to children. We asked whether (1) parental causal language input differed for different types of play, and (2) early parental causal language input predicted children's later causal verb understanding. We had three hypotheses. First, based on the previous findings, we expected that parents would use more causal language in the guided play contexts compared to the free play contexts (Ferrara et al., 2011). In the guided play contexts, parents might use more directive language to assist their children in completing the puzzles manually, and as a result, these directive language constructions would include more causal structures than the ones in the free play contexts. Second, for both play contexts, we expected that parental causal input would increase from Time 1 to Time 2 to scaffold children's developing language skills. Third, we predicted that early overall parental causal input would predict later child causal verb comprehension but not non-causal verb comprehension. Last, morphological causal verb input would be a better predictor of causal verb understanding than lexical causal verb input as it provides more cues for the child to extract causal meaning. Given the scarcity of earlier work, we did not have specific hypotheses for how lexical and morphological causal input would differ for different contexts.

\section{Method}

\section{Participants}

Twenty-nine infants (15 females) participated at three timepoints: Time $1 \quad(M=14.51$ months, $S D=1.45)$, Time $2 \quad(M=19.21$ months, $S D=1.32)$, and Time $3(M=34.76$ months, $S D=1.56)$. All participants were monolingual native speakers of Turkish from upper-middle-class families. Children were tested at daycare centers, where they attended playgroups with their mothers. The study was approved by [Blinded University is Koç University] University's Institutional Review Board (Project name: Turkish learning children's relational word learning: A longitudinal study - Protocol no: 2014.052.IRB.2.015).

\section{Materials and procedure}

Time 1 and Time 2 parent-infant play sessions

At Times 1 and 2, we recorded parent-infant play sessions for two types of play: (1) free play (i.e., a felt school/vehicles and a parking lot), and (2) guided play (i.e., puzzles to be completed) (see Figure 1 for details of the stimuli). Each play session lasted about 3 to 4 minutes for both types of plays. Parent-infant dyads first completed free play and then moved on to guided play. For free plays, parents were instructed to play with the toys together with their children as they wished. For guided plays, parents were instructed to complete the puzzles given to them together with their children as they were playing. In these guided plays, parent-child dyads had a final goal to complete the puzzles. 

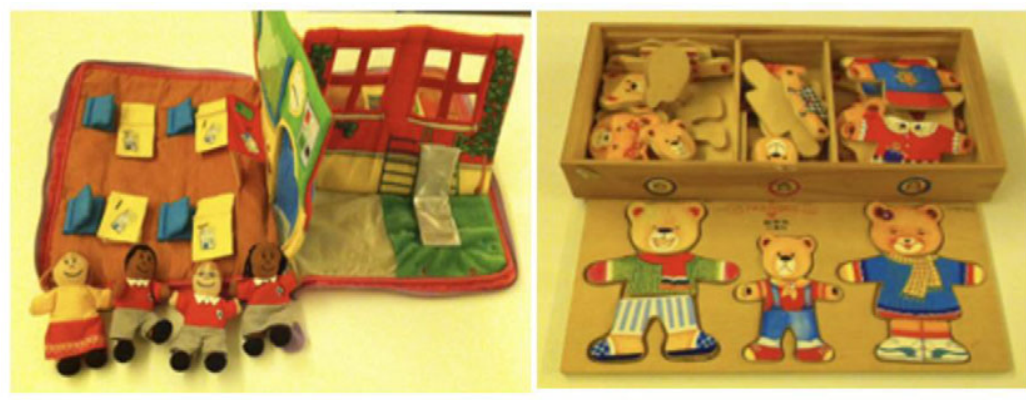

(a)

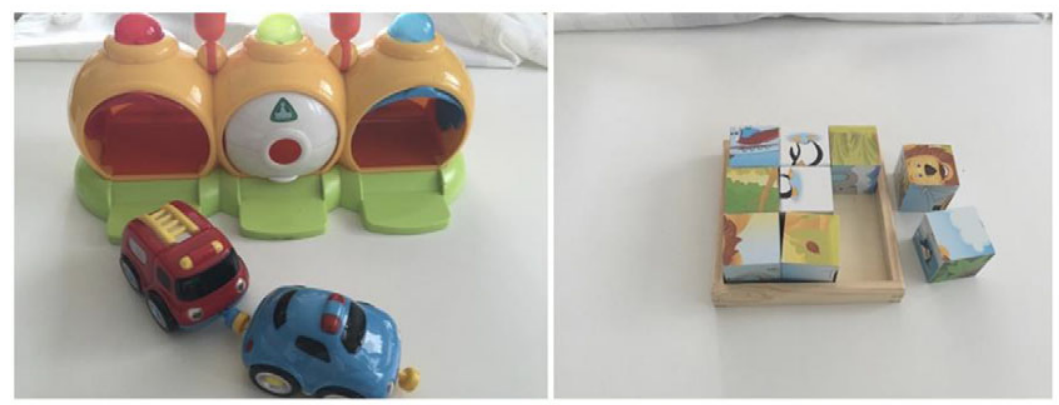

Figure 1. Free play and guided play toys: Time 1- (a), Time 2 (b)

For Time 1, we used a felt school with felt figures for free play purposes. We introduced different school sections (e.g., playground, café, and classroom) to acquaint parent-child dyads with the toy set. For the guided play, we presented a wooden puzzle toy that contained pieces of different sizes and patterns, depicting the body parts of the mother, father, and baby bear (head, torso, legs). The goal of the game was to complete different mother, father, and baby bear alternatives; as some parts did not fit specific bears, there was an inherent goal to form a correct bear.

For Time 2, we used plastic cars and a parking lot for free play. There were three cars, which could be magnetically attached. Parking lots had lids that the child could easily open. For the guided play, we used a 9-piece cube puzzle. There were six target pictures, each target picture corresponded to one side of the cubes. The task was to choose one of the six target pictures and complete the puzzle using the nine cubes.

We used different sets of toys for Times 1 and 2. Since there were only approximately 5 to 6 months between two sessions, we wanted to avoid parents' familiarity particularly with puzzle toys (i.e., having solved the puzzle earlier might have an effect on how parents talked to their children), so that the familiarity of the toys would not drive language input.

\section{Coding of parent - infant play sessions}

We coded play sessions based on two main coding schemes: (1) Linguistic complexity, and (2) Causal language. Linguistic complexity was coded as an overall characteristic of linguistic input. For each parent-infant conversation, we coded all simple and complex clauses parents used. Then, we calculated the LINGUISTIC COMPLEXITY SCORE by taking the 
percentage of complex clauses with respect to the total number of clauses (see Table 1 for the coding details). We took the linguistic complexity score as a control variable for the overall input in our analyses.

The causal language was coded based on causal verbs as well as causal connectors. Causal verbs fall into two categories: (1) LEXICAL causatives, and (2) MORPHOLOGICAL causatives. Lexical causative verbs inherently encode cause and effect (result). Morphological causatives are formed by converting a non-causative verb into a causative one using a causative suffix. We also coded causal connectors that included words or phrases to introduce a cause for a given action or result in a sentence (see Table 2 for the coding scheme). Due to the small number of occurrences of causal connectors, we excluded them from calculations and analyses. Thus, we formed two scores for causal language input: (1) proportion of lexical causatives, and (2) proportion of morphological causatives. We calculated each score by dividing the total number of lexical causal verbs/morphological causal verbs by the total number of clauses. For complex sentences containing coordination or subordination, we counted the actual number of clauses within these sentences.

Table 1. Linguistic complexity coding scheme

\begin{tabular}{|c|c|c|c|c|}
\hline $\begin{array}{l}\text { Linguistic } \\
\text { Complexity } \\
\text { Components }\end{array}$ & Categories & Definitions & $\begin{array}{l}\text { Turkish } \\
\text { Examples }\end{array}$ & $\begin{array}{l}\text { English } \\
\text { Translations }\end{array}$ \\
\hline $\begin{array}{l}\text { Simple } \\
\text { clause }\end{array}$ & - & A clause with one predicate & Buraya gel. & 'Come here.' \\
\hline \multirow[t]{4}{*}{$\begin{array}{l}\text { Complex } \\
\text { clauses }\end{array}$} & $\begin{array}{r}\text { Infinitival } \\
\text { clauses }\end{array}$ & $\begin{array}{l}\text { A clause with two predicates } \\
\text { joined by the -mek-mak } \\
\text { construction in Turkish }\end{array}$ & $\begin{array}{l}\text { Açmaya } \\
\text { çalışayım. }\end{array}$ & $\begin{array}{l}\text { 'Let me try } \\
\text { to open.' }\end{array}$ \\
\hline & $\begin{array}{c}\text { Coordinate } \\
\text { clauses }\end{array}$ & $\begin{array}{l}\text { Two clauses joined with a } \\
\text { coordinating conjunction } \\
\text { such as: ve 'and', ama 'but', } \\
\text { sonra 'then', sonunda 'at last' } \\
\text { buna rağmen, 'however', } \\
\text { çünkü, 'because' }\end{array}$ & $\begin{array}{l}\text { O oraya } \\
\text { girmez } \\
\text { çüinkü } \\
\text { büyük. }\end{array}$ & $\begin{array}{l}\text { 'That won't } \\
\text { fit in there } \\
\text { since it's } \\
\text { big.' }\end{array}$ \\
\hline & $\begin{array}{l}\text { Subordination } \\
\text { with adverbial } \\
\text { and } \\
\text { complement } \\
\text { clauses }\end{array}$ & $\begin{array}{l}\text { Two clauses joined by a } \\
\text { subordinating conjunction } \\
\text { such as } \\
\text {-dığı zaman 'when' } \\
\text {-sa/-se 'if' } \\
\text {-dığı için 'for that reason' } \\
\text {-dıktan sonra, 'after' 'while' } \\
\text { 'so' }\end{array}$ & $\begin{array}{l}\text { Öyle } \\
\text { koyarsan } \\
\text { düşer. }\end{array}$ & $\begin{array}{l}\text { 'If you put } \\
\text { that way } \\
\text { it'll fall.' }\end{array}$ \\
\hline & $\begin{array}{l}\text { Subordination } \\
\text { with converbs }\end{array}$ & $\begin{array}{l}\text { Two clauses joined as } \\
\text { Verb+ken, koşarken 'while } \\
\text { running' } \\
\text { Verb+ince, koşunca 'when } \\
\text { ran' } \\
\text { Verb+ip, koşup, 'running' } \\
\text { Verb+erek, koşarak, 'by } \\
\text { means of running' } \\
\text { Verb+a V+a, koşa koşa 'in the } \\
\text { manner of running' }\end{array}$ & $\begin{array}{l}\text { Hoplayarak } \\
\text { mı } \\
\text { kayıyor } \\
\text { bu çocuk? }\end{array}$ & $\begin{array}{l}\text { 'Does that } \\
\text { child slide } \\
\text { hopping- } \\
\text { ly?' }\end{array}$ \\
\hline
\end{tabular}


Table 2. Causal language coding scheme

\begin{tabular}{|c|c|c|}
\hline $\begin{array}{l}\text { Causal } \\
\text { Language } \\
\text { Components }\end{array}$ & Definition & Examples \\
\hline $\begin{array}{l}\text { Lexical } \\
\text { causatives }\end{array}$ & $\begin{array}{l}\text {-verbs that inherently encode cause } \\
\text { and effect }\end{array}$ & $\begin{array}{l}\text { - at 'throw', çevir 'rotate', döndür 'spin', } \\
\text { kır 'break', eğ 'bend' etc. }\end{array}$ \\
\hline $\begin{array}{l}\text { Morphological } \\
\text { causatives }\end{array}$ & -causal verbs created by suffixes & $\begin{array}{l}\text { - verbs formed with suffixes that create } \\
\text { morphological causatives (e.g., -Dır, } \\
\text {-ır, -ar, - } t \text { t) } \\
\text { ye-Dir 'make some one eat', } \\
\text { kop-ar 'break off' } \\
\text { kork-ut 'make someone scared' } \\
\text { çık-art 'take off' }\end{array}$ \\
\hline $\begin{array}{l}\text { Causal } \\
\text { connectors }\end{array}$ & $\begin{array}{l}\text { - words or phrases that are used to } \\
\text { introduce a cause for a given action } \\
\text { or result }\end{array}$ & $\begin{array}{l}\text { - Eğer öyle çekersen düşer } \\
\text {-'If you pull that way, it will fall' } \\
\text { - Döndürüyorum yoksa sığmayacak } \\
\text {-'I am turning since it won't fit otherwise' }\end{array}$ \\
\hline
\end{tabular}

\section{Time 3 Tasks: TIFALDI-E}

At Time 3, children completed TIFALDI (Turkish Expressive and Receptive Language Test- Expressive subtest) (Berument \& Güven, 2010). We used this test to obtain a general language score from children and control for children's general expressive language skills in predicting causal verb understanding through parental input. This test measures the expressive vocabulary of children aged from 2 to 12 years. The test includes 80 items, each having a picture that depicts the target word. Children were instructed to tell the name of the object presented in the picture. The task took 15 to 20 minutes to complete.

\section{Time 3 Tasks: Verb Comprehension Task}

The task was adapted from Konishi, Stahl, Golinkoff and Hirsh-Pasek (2016), in which children were presented with a split-screen depiction of actions (for the Turkish version, see Aktan-Erciyes \& Göksun, 2019). The task consisted of 20 trials. In each trial, children were presented with two video clips that played simultaneously on a split-screen where a human actor performed similar actions (e.g., running vs. walking). Before the test, children were given two practice trials that included common objects (e.g., cake vs. hamburger) to ensure they could point at the instructed stimulus. Eight trials contained non-causal verbs, and 12 trials consisted of causal verbs. Of all 12 pairs of causal verbs (a total of 24 verbs), there were 4 morphological causative verbs and, the rest were lexical causative verbs. Children were tested on each verb once, and they saw each verb pair only once. The experimenter asked the child to point to the target action (e.g., Which one is running?) as the video clips started. Video clips were presented up to two times in case the child did not give any response. After the second display, if there had still been no response from the child, the experimenter would have continued with the next trial. Children were assigned to one of the two conditions in which verb pairs were randomly ordered (see Table 3 for all verb pairs and instructions). All children watched the same verb pairs; however, the target verb changed across the two conditions. For example, in Condition 1, we asked which actor was 'running', whereas Condition 2 asked 
Table 3. The verb pairs and instructions used in the experiment

\begin{tabular}{|c|c|c|c|c|}
\hline \multirow{2}{*}{\multicolumn{2}{|c|}{ Non-causal verb pair }} & & \multicolumn{2}{|c|}{ Instruction } \\
\hline & & & English & Turkish \\
\hline wave & point & & $\begin{array}{l}\text { which one is waving/ } \\
\text { pointing? }\end{array}$ & $\begin{array}{l}\text { hangisi el salliyor/ } \\
\text { işaret ediyor? }\end{array}$ \\
\hline run & walk & & $\begin{array}{l}\text { which one is running/ } \\
\text { walking? }\end{array}$ & $\begin{array}{l}\text { hangisi koşuyor/ } \\
\text { yürüyor }\end{array}$ \\
\hline creep & crawl & & $\begin{array}{l}\text { which one is creeping/ } \\
\text { crawling? }\end{array}$ & $\begin{array}{l}\text { hangisi sürünüyor/ } \\
\text { emekliyor? }\end{array}$ \\
\hline crouch & stand up & & $\begin{array}{l}\text { which one is crouching/ } \\
\text { standing up? }\end{array}$ & $\begin{array}{c}\text { hangisi çömeliyor/ } \\
\text { ayağa kalkıyor? }\end{array}$ \\
\hline dance & turn & & $\begin{array}{l}\text { which one is dancing/ } \\
\text { turning? }\end{array}$ & $\begin{array}{l}\text { hangisi dans ediyor/ } \\
\text { dönüyor? }\end{array}$ \\
\hline sit & stand up & & $\begin{array}{l}\text { which one is sitting/ } \\
\text { standing up? }\end{array}$ & $\begin{array}{l}\text { hangisi oturuyor/ } \\
\text { ayağa kalkıyor? }\end{array}$ \\
\hline hug & blow kiss & & $\begin{array}{l}\text { which one is hugging/ } \\
\text { blowing kiss? }\end{array}$ & $\begin{array}{l}\text { hangisi sarılıyor/ } \\
\text { öpücük yolluyor? }\end{array}$ \\
\hline jump & lie down & & $\begin{array}{l}\text { which one is jumping/ } \\
\text { lying down? }\end{array}$ & $\begin{array}{c}\text { hangisi zıpliyor/yere } \\
\text { yatıyor? }\end{array}$ \\
\hline Causal & rb pair & Direct object & & \\
\hline pull & push & chair & $\begin{array}{c}\text { which one is pulling/ } \\
\text { pushing the chair? }\end{array}$ & $\begin{array}{l}\text { hangisi sandalyeyi } \\
\text { çekiyor/itiyor? }\end{array}$ \\
\hline eat & peel off & banana & $\begin{array}{l}\text { which one is eating/ } \\
\text { peeling off the banana? }\end{array}$ & $\begin{array}{l}\text { hangisi muzu yiyor/ } \\
\text { soyuyor? }\end{array}$ \\
\hline open & cover & scarf & $\begin{array}{l}\text { which one is opening/ } \\
\text { covering the scarf? }\end{array}$ & $\begin{array}{l}\text { hangisi örtüyü } \\
\text { açıyor/kapıyor? }\end{array}$ \\
\hline drink & pour & water & $\begin{array}{c}\text { which one is drinking/ } \\
\text { pouring the water? }\end{array}$ & $\begin{array}{l}\text { hangisi suyu içiyor/ } \\
\text { döküyor? }\end{array}$ \\
\hline throw & hold & ball & $\begin{array}{c}\text { which one is throwing/ } \\
\text { holding the ball? }\end{array}$ & $\begin{array}{l}\text { hangisi topu atiyor/ } \\
\text { tutuyor? }\end{array}$ \\
\hline $\begin{array}{l}\text { take } \\
\text { off }\end{array}$ & put on & hat & $\begin{array}{l}\text { which one is taking } \\
\text { off/putting on the hat? }\end{array}$ & $\begin{array}{l}\text { hangisi şapkayı } \\
\text { çıkarıyor/takıyor? }\end{array}$ \\
\hline blow & burst & balloon & $\begin{array}{l}\text { which one is blowing/ } \\
\text { bursting the balloon? }\end{array}$ & $\begin{array}{l}\text { hangisi balonu } \\
\text { patlatıyor/ } \\
\text { şişiriyor? }\end{array}$ \\
\hline open & close & umbrella & $\begin{array}{l}\text { which one is opening/ } \\
\text { closing the umbrella? }\end{array}$ & $\begin{array}{l}\text { hangisi şemsiyeyi } \\
\text { açıyor/kapıyor? }\end{array}$ \\
\hline light & blow & candle & $\begin{array}{l}\text { which one is lighting/ } \\
\text { blowing the candle? }\end{array}$ & $\begin{array}{l}\text { hangisi mumu } \\
\text { yakıyor/ } \\
\text { söndürüyor? }\end{array}$ \\
\hline put on & take off & jacket & $\begin{array}{l}\text { Which one is putting } \\
\text { on/taking off the } \\
\text { jacket? }\end{array}$ & $\begin{array}{l}\text { hangisi ceketi } \\
\text { giyiyor/çıkarıyor? }\end{array}$ \\
\hline open & shut & lid & $\begin{array}{l}\text { which one is opening/ } \\
\text { shutting the lid? }\end{array}$ & $\begin{array}{l}\text { hangisi kapağı } \\
\text { açıyor/kapatıyor? }\end{array}$ \\
\hline tie & pull off & string & $\begin{array}{l}\text { which one is tying/pulling } \\
\text { off the string? }\end{array}$ & $\begin{array}{l}\text { hangisi ipi bağliyor/ } \\
\text { çekiyor? }\end{array}$ \\
\hline
\end{tabular}


Table 4. Means and standard deviations of Time 1, 2, 3 measures

\begin{tabular}{lcccc}
\hline & Mean & SD & Min & Max \\
\hline T1 free play - lexical causative & .08 & .05 & 0 & .18 \\
\hline T1 free play - morphological causative & .09 & .08 & .01 & .30 \\
\hline T1 free play linguistic complexity & .12 & .08 & 0 & .33 \\
\hline T1 guided play - lexical causative & .20 & .08 & .07 & .32 \\
\hline T1 guided play - morphological causative & .04 & .04 & 0 & .14 \\
\hline T1 guided play linguistic complexity & .13 & .07 & 0 & .21 \\
\hline T2 free play - lexical causative & .18 & .13 & .08 & .67 \\
\hline T2 free play - morphological causative & .05 & .03 & .10 & .44 \\
\hline T2 free play linguistic complexity & .14 & .10 & 0 & .32 \\
\hline T2 guided play - lexical causative & .38 & .10 & .20 & .64 \\
\hline T2 guided play - morphological causative & .05 & .07 & .00 & .23 \\
\hline T2 guided play linguistic complexity & .14 & .09 & 0 & .31 \\
\hline T3 TíFALDİ-E & 33 & 5.28 & 22 & 47 \\
\hline T3 Overall verb comprehension & .74 & .22 & .03 & .97 \\
\hline T3 Causal verb comprehension & .72 & .26 & .00 & 1.00 \\
\hline T3 Non-causal verb comprehension & .76 & .23 & .08 & 1.00 \\
\hline
\end{tabular}

which one was 'walking' (see Table 4 for all means and standard deviations of Time 1, 2, and 3 measures). This task took about 6 to 8 minutes to complete for each child. Children first completed the verb comprehension task, then moved on to TİFALDİ-E.

\section{Results}

We asked whether (1) parental causal language input differed for different types of play at two timepoints during children's first two years, and (2) early parental causal language input was associated with children's later causal verb understanding. As a preliminary analysis, we compared the total number of utterances for different types of play for two time points. Results indicated that parents used similar numbers of utterances for free play and guided play both at Times 1 and $2,(t(28)=.51, p=.61, t(28)=-.56, p=.57)$.

\section{Comparison of maternal causal input across play types and timepoints}

For our first research question, we compared free and guided play sessions for Time 1 and Time 2. We conducted a repeated-measures-ANOVA, taking play type (free play, guided play), causal input type (lexical vs. morphological), and time (Time 1 and Time 2) as within-subject variables (see Figure 2 and Table 4 for details). We used Bonferroni correction for post-hoc t-tests. Results indicated significant main effects of play type, causal input type, and time, $F(1,27)=24.21, p<.001, \eta_{p}{ }^{2}=.54, F(1,27)=112.83, p<.001, \eta_{p}{ }^{2}$ $=.84, F(1,27)=41.18, p<.001, \eta_{p}{ }^{2}=.67$, respectively. There was a significant interaction 


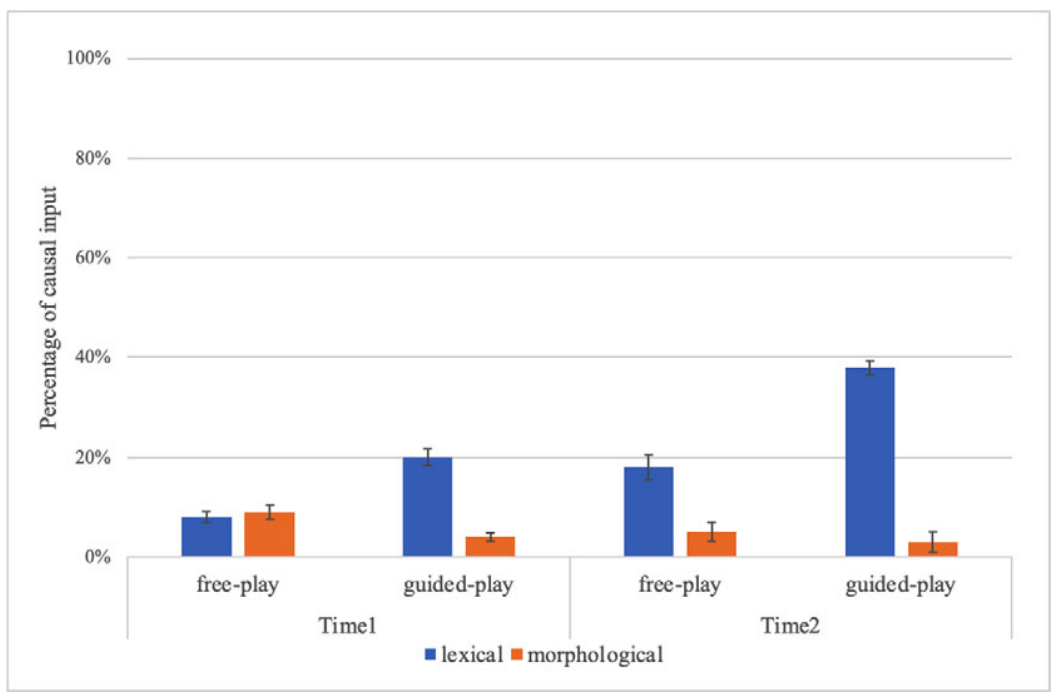

Figure 2. Parental lexical vs. morphological causal input across play types and timepoints

between play type and causal input type, $F(1,27)=22.48, p<.001, \eta_{p}{ }^{2}=.53$. There was no significant interaction between time and play type, $F(1,27)=.07, p=.782, \eta_{p}{ }^{2}=.004$.

The three-way interaction of time, causal input, and play type was also significant, $F(1,27)=14.65, p<.001, \eta_{p}{ }^{2}=.42$. When we considered the play type, results indicated that during guided play, parents provided more lexical than morphological causatives, for both Time 1 and Time $2, t(28)=6.84, p<.001$ and $t(28)=12.89, p<.001$, respectively. On the other hand, during free play, they provided more lexical than morphological causatives at Time 2, but not for Time $1, t(28)=11.15, p<.001$ and $t(28)=.841, p=.44$, respectively.

When we considered the causal input type, results revealed that lexical causatives increased from Time 1 to Time 2, whereas morphological causal input decreased from Time 1 to Time $2, t(28)=3.95, p<.001$ and $t(28)=11.15, p<.001$, respectively. Additionally, post-hoc tests for time-related changes revealed that the amount of lexical causative input was greater in guided play than in free play for both Time 1 and Time $2, t(28)=3.21$, $p<.01$ and $t(28)=6.74, p<.001$, respectively. However, morphological causal input did not differ across play types neither at Time 1 nor at Time $2, t(28)=1.17, p>.05$ and $t(28)=1.01$, $p>.05$, respectively.

\section{Relations between early maternal causal input and later causal verb understanding}

To investigate relations between early parental causal input (Time $1 \&$ Time 2) and later causal verb understanding at Time 3, we conducted hierarchical linear regression analyses, taking either free play or guided play variables as predictors, controlling for age, the overall vocabulary of children, and parental linguistic complexity in play sessions. We predicted that early parental causal input would specifically be related to causal verb comprehension. For both timepoints, we examined the same variables, linguistic complexity, and lexical and morphological causal input. Therefore, we computed composite 
scores for these variables for each play type: Time 1-Time 2 free play linguistic complexity, Time 1-Time 2 guided play linguistic complexity, and Time 1 and Time 2 composite scores for lexical and morphological causal input. We used these composite scores in the regression analyses.

We tested four models. The first two models included Time 3 non-causal verb comprehension as outcome variables. The predictors were age at Time 3, Time 3 TIFALDI scores, linguistic complexity composite score (either free play (Model 1) or guided play (Model 2)), morphological and lexical causal input composite scores in corresponding play sessions. None of these models (Model 1 and Model 2) predicting non-causal verb comprehension were significant (see Tables 5 and 6).

In the next two models (Model 3 and Model 4), we predicted Time 3 causal verb comprehension as outcome variables (see Tables 7 and 8). In Model 3, we predicted Time 3 causal verb comprehension through free play predictors. We included five predictors as indicated in the above section: Time 3 age, Time 3 TIFALDI scores, linguistic complexity composite score of the free play, and last morphological and lexical causal composite input variables. In the first step, Time 3 age and Time 3 TIFALDI scores did not contribute to the first model, $F(2,25)=2.53, p=.10$. In the second step, we introduced free play linguistic complexity in the model. Again, the model was not significant in explaining the variance in causal verb comprehension, $F(3,24)=1.68, p=.21$. Last, when lexical and morphological causal input variables were introduced, an additional $28 \%$ of the variance was explained, the model was significant in explaining $46 \%$ of the total variance $\left(R^{2}=.46, F(5,22)=3.52, p=.02\right)$. The only significant predictor was morphological causal input $(\beta=.57, p=.01)$. Results indicated that early morphological causal input in free play was positively associated with later causal verb comprehension (see Figure 3).

Table 5. Parental Causal Input in Free Play Predicting Non-Causal Verb Comprehension

\begin{tabular}{lcccccc}
\hline Outcome: Time 3 Non-casual Verb Comprehension & & & & & \\
\hline Predictors & $\beta$ & $p$ & $R^{2}$ & $\Delta R^{2}$ & F-Change \\
\hline Step 1 & & & 0.16 & 0.16 & 2.33 \\
\hline T3 Age & 0.27 & 0.15 & & & \\
\hline T3 TIFALDI & 0.31 & 0.11 & & & \\
\hline Step 2 & & & 0.19 & 0.03 & 0.91 \\
\hline T3 Age & 0.33 & 0.10 & & & \\
\hline T3 TIFALDI & 0.35 & 0.08 & & & \\
\hline T1-T2 Free play linguistic complexity & 0.19 & 0.35 & & & \\
\hline Step 3 & & & 0.23 & 0.04 & 0.52 \\
\hline T3 Age & 0.29 & 0.17 & & & \\
\hline T3 TIFALDI & 0.30 & 0.14 & & & \\
\hline T1-T2 Free play linguistic complexity & 0.19 & 0.35 & & & \\
\hline T1-T2 Free play lexical causal input & 0.14 & 0.48 & & & \\
\hline T1-T2 Free play morphological causal input & 0.15 & 0.45 & & & \\
\hline
\end{tabular}


Table 6. Parental Causal Input in Guided Play Predicting Non-Causal Verb Comprehension

\begin{tabular}{|c|c|c|c|c|c|}
\hline \multicolumn{6}{|l|}{ Outcome: Time 3 Non-causal Verb Comprehension } \\
\hline Predictors & $\beta$ & $p$ & $R^{2}$ & $\Delta R^{2}$ & F-Change \\
\hline Step 1 & & & 0.08 & 0.08 & 0.88 \\
\hline T3 Age & 0.26 & 0.25 & & & \\
\hline T3 TIFALDI & 0.17 & 0.45 & & & \\
\hline Step 2 & & & 0.20 & 0.12 & 2.95 \\
\hline T3 Age & 0.35 & 0.12 & & & \\
\hline T3 TIFALDI & 0.31 & 0.18 & & & \\
\hline T1-T2 Guided play linguistic complexity & 0.39 & 0.10 & & & \\
\hline Step 3 & & & 0.23 & 0.03 & 0.31 \\
\hline T3 Age & 0.29 & 0.24 & & & \\
\hline T3 TIFALDI & 0.30 & 0.23 & & & \\
\hline T1-T2 Guided play linguistic complexity & 0.45 & 0.09 & & & \\
\hline T1-T2 Guided play lexical causal input & 0.14 & 0.62 & & & \\
\hline T1-T2 Guided play morphological causal input & 0.23 & 0.44 & & & \\
\hline
\end{tabular}

Table 7. Parental Causal Input in Free Play Predicting Causal Verb Comprehension

\begin{tabular}{|c|c|c|c|c|c|}
\hline \multicolumn{6}{|l|}{ Outcome: Time 3 Causal Verb Comprehension } \\
\hline Predictors & $\beta$ & $p$ & $R^{2}$ & $\Delta R^{2}$ & F-Change \\
\hline Step 1 & & & 0.17 & 0.17 & 2.53 \\
\hline T3 Age & 0.31 & 0.11 & & & \\
\hline T3 TIFALDI & 0.29 & 0.13 & & & \\
\hline Step 2 & & & 0.17 & 0.00 & 0.00 \\
\hline T3 Age & 0.31 & 0.13 & & & \\
\hline T3 TIFALDI & 0.30 & 0.15 & & & \\
\hline T1-T2 Free play linguistic complexity & 0.01 & 0.95 & & & \\
\hline Step 3 & & & 0.46 & 0.28 & 5.44 \\
\hline T3 Age & 0.12 & 0.51 & & & \\
\hline T3 TIFALDI & 0.18 & 0.30 & & & \\
\hline T1-T2 Free play linguistic complexity & -0.03 & 0.89 & & & \\
\hline T1-T2 Free play lexical causal input & 0.04 & 0.83 & & & \\
\hline T1-T2 Free play morphological causal input & 0.57 & 0.003 & & & \\
\hline
\end{tabular}


Table 8. Parental Causal Input in Guided Play Predicting Causal Verb Comprehension

\begin{tabular}{|c|c|c|c|c|c|}
\hline \multicolumn{6}{|l|}{ Outcome: Time 3 Causal Verb Comprehension } \\
\hline Predictors & $\beta$ & $p$ & $R^{2}$ & $\Delta R^{2}$ & F-Change \\
\hline Step 1 & & & 0.09 & 0.09 & 0.96 \\
\hline T3 Age & 0.17 & 0.46 & & & \\
\hline T3 TIFALDI & 0.28 & 0.23 & & & \\
\hline Step 2 & & & 0.12 & 0.03 & 0.55 \\
\hline T3 Age & 0.21 & 0.38 & & & \\
\hline T3 TIFALDI & 0.35 & 0.17 & & & \\
\hline T1-T2 Guided play linguistic complexity & 0.18 & 0.47 & & & \\
\hline Step 3 & & & 0.17 & 0.05 & 0.46 \\
\hline T3 Age & 0.22 & 0.42 & & & \\
\hline T3 TIFALDI & 0.41 & 0.14 & & & \\
\hline T1-T2 Guided play linguistic complexity & 0.12 & 0.67 & & & \\
\hline T1-T2 Guided play lexical causal input & -0.28 & 0.36 & & & \\
\hline T1-T2 Guided play morphological causal input & -0.14 & 0.69 & & & \\
\hline
\end{tabular}

Last, in Model 4 to predict Time 3 causal verb comprehension through guided play predictors, we again included five predictors: Time 3 age, Time 3 TIFALDI scores, linguistic complexity composite score of the guided play, and last morphological and lexical causal input variables for guided play. In the first step, the model was not significant when we introduced Time 3 age and Time 3 TIFALDI scores, $F(2,25)=.96$, $p=.40$. In the second step, we introduced the linguistic complexity of guided play sessions; and the model was again not significant, $F(3,24)=.81, p=.51$. In the final step, guided play lexical and morphological input scores were introduced, and the model was not significant in explaining the variance in causal verb comprehension, $F(5,22)=.64, p=$ .68 (see Table 8).

\section{Discussion}

This study investigated early parental causal input for different play contexts in the first two years of children's lives and its relations to children's later causal verb understanding at the end of their third year. We asked two main questions: (1) Did parental causal language input differ for different play contexts and timepoints during children's first two years? and (2) Did early parental causal language input predict children's later causal verb understanding? We tested children at three time points: Time 1 (12- to 16-month-olds), Time 2 (18- to 22-month-olds), and Time 3 (32- to 39-month-olds). The three-way interaction indicated that lexical causatives were more frequent than morphological ones at both time points for guided play. For free play, lexical causatives were more frequent than morphological causatives at Time 2, yet there was no difference between lexical and morphological ones at Time 1 . We also showed that parental causal input for lexical causatives was greater in guided play contexts compared to free play contexts for both 


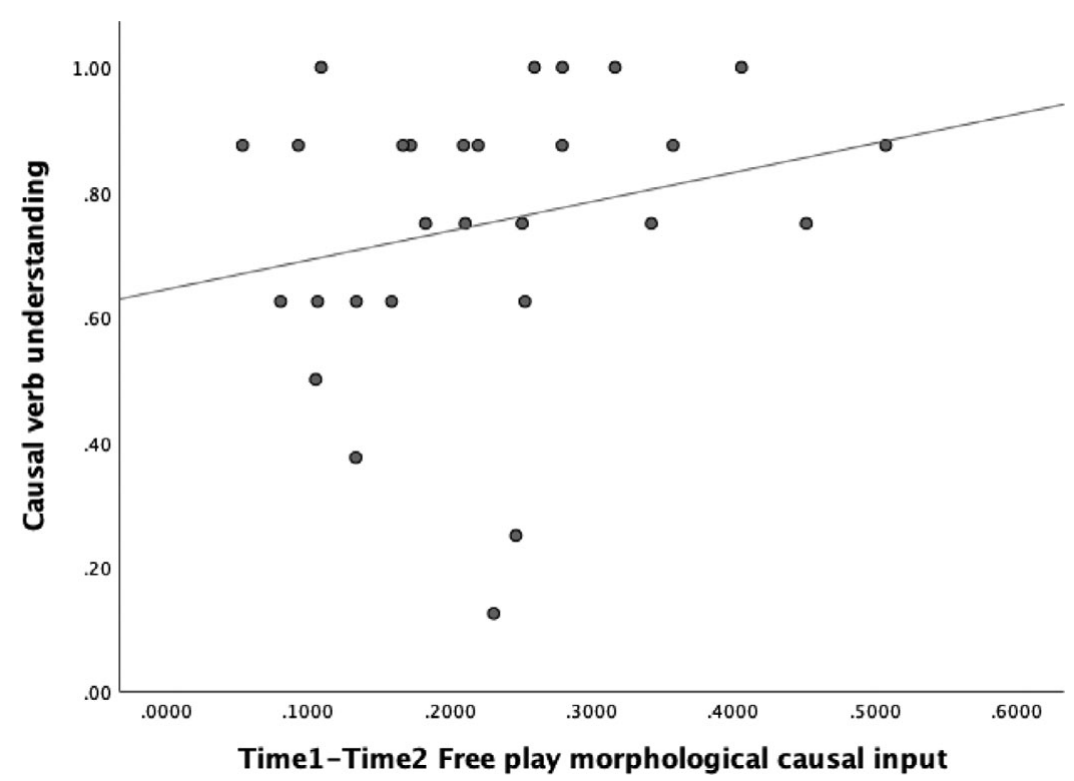

Figure 3. Children's causal verb understanding in relation to free play morphological causal input

timepoints. However, for morphological causatives, which might be more context dependent, the same difference did not hold. Last, early parental morphological causal input from free play contexts was associated with children's later understanding of causal verbs. No relation between either type of input and causal verb comprehension was found for the guided play contexts.

The first goal of this study was to examine whether causal language input differed based on play types and children's age in their second year of life. Previous research indicates that different play contexts elicit different parental language input (Lewis \& Gregory, 1987; O’Brien \& Nagle, 1987). Based on the constructivist views of learning, during free play, a learner is actively involved in the play, acting upon the environment and updating information while interacting with the environment (Piaget, 1954). Guided play involves both dynamic and interactive properties to the learner as it also allows guidance from the parent (Yu, Shafto, Bonawitz, Yang, Golinkoff, Corriveau, Hirsh-Pasek $\& \mathrm{Xu}, 2018)$. In that sense, guided play is suggested to lie between direct instruction and free play (Weisberg et al., 2013a). Most research on guided play focuses on educational settings (Weisberg et al., 2013b; Weisberg, Hirsh-Pasek, Golinkoff, Kittredge \& Klahr, 2016; but see Ferrara et al., 2011) or whether children benefit from guided play instructions for learning concepts such as geometric shapes (Fisher et al., 2011). In this study, we examined a specific input type, i.e., causal input, in both free play and guided play. Results indicated that lexical causative input in guided play was greater than in free play for both Time 1 and Time 2. The difference was not found for morphological causatives. Findings regarding lexical causative input are in line with previous work showing that parents used less directive language during free play compared to toy play to reach a certain goal (Ferrara et al., 2011). In guided play contexts of the present study, to fulfill the common goal, parental use of causal language, especially lexical causal verbs, might be more pronounced. We used puzzles for guided play sessions, and parents directed their children 
for the next moves by using more causal verbs such as put, turn, place to complete the puzzles, eliciting causal language, particularly in the form of lexical causatives more for guided play than free play activities.

We also expected that overall parental causal input would increase from Time 1 to Time 2. We found an interaction between causal input and time, which indicated that although lexical causal input increased between two time points, morphological causal input decreased from Time 1 to Time 2. This unexpected finding might be a result of both the Time 2 guided play toy (i.e., nine puzzle cubes) and the Time 1 free play toys. For Time 2 guided play, the task for the parent and child was to complete a predetermined chosen picture (out of 6 alternatives) with puzzle cubes, which had 6 alternative pictures on each side. The completion of the puzzle was too difficult for almost every parent-child dyad. In fact, only a few dyads completed the puzzle correctly. The parents who found the task difficult might have avoided using morphological verbs. Instead, they predominantly produced common lexical causatives such as 'turn' and 'place'. There was also a significant three-way interaction between play type, causal input, and time. Results indicated that for Time 1 free play session, there was no difference between lexical causatives and morphological causatives; however, at Time 2 for free play, lexical causatives were more frequent than morphological causatives. This might be the result of the fact that Time 1 free play toy elicited unexpectedly more morphological causal verbs, and therefore the difference between lexical and morphological input has disappeared. Time 1 free play included animate toy characters (e.g., teacher and students) and activity spots such as cafeteria and playground. Thus, parents often directed their children to make students eat (in Turkish morphological verb as ye-dir) or make them slide down (in Turkish morphological verb as kay-dir), which involved them using morphological causal verbs. However, for Time 2, this was not the case. Therefore, we conclude that this could be due to the toys we used. This finding is in line with the previous literature that regardless of the context specific toys may elicit differential language input (Lewis \& Gregory, 1987; O'Brien \& Nagle, 1987; Thippana et al., 2020). Additionally, for guided play, parents used lexical causal input more than morphological at both timepoints. Overall, the present study has a limitation of using different toys at two timepoints that might elicit diverse inputs for types of play. Our decision of choosing different toys for Times 1 and 2 was motivated by avoiding parents' familiarity with toys that might elicit similar language input; however, the context of the play (i.e., playground vs. vehicles) might also have confounded the results. Therefore, careful interpretation of these results is necessary.

We assessed how specific parental causal input (i.e., lexical vs. morphological) differed across play contexts at two timepoints. Given the scarcity of previous work on parental input and children's production of lexical and morphological causatives, we did not have any specific predictions (see Ketrez, 1999). Our results revealed a significant three-way interaction between play type, causal input type, and timepoint. Although there was no difference between lexical and morphological input for free play context for Time 1 , parents used more lexical causatives than morphological causatives for guided play contexts at both timepoints and for Time 2 free play context. The lack of difference between lexical and morphological input for free play in Time 1 might be due to the toy chosen. The school toy had both a playground and a café, which elicited two dominant morphological verbs for Turkish (kay-dir 'to make someone slide,' and ye-dir 'to make someone eat') and increased the number of morphological verb inputs for this task. Parents used more lexical causal verbs than morphological ones for other play instances. Unlike the free play toys, puzzles in the guided play contexts encouraged parents to use many lexical causal verbs (e.g., çevir 'turn,' sok 'insert', koy 'place'). This finding aligns 
with previous literature that certain play contexts elicit specific language input (e.g., Eason \& Ramani, 2020). For instance, parents in guided play context used more spatial language compared to free play context while playing with blocks (Ferrara et al., 2011). Overall, results indicated that except for free play at Time 1, parents used more lexical causatives compared to morphological causatives. This might be both due to the greater frequency of lexical causal verbs than morphological causal verbs in Turkish (Göksel \& Kerslake, 2005) and the role of context. For instance, Altınkamış, Kern and Sofu (2014) compared two typologically different languages, Turkish and French, for different contexts (object vs. action-oriented utterances). Results indicated that regardless of the language typology, mothers used more verbs compared to nouns for action-oriented utterances compared to object-oriented ones. Thus, context might override dominant language-specific use.

Our last hypothesis expected that early parental causal input would specifically predict children's later understanding of causal verbs. As parents produced more causal language early on, children would be better at causal verb comprehension. Relying on the transparent cues of semantic causality that morphological causal verbs provide, we expected that morphological causal verb input would be a better predictor than lexical causal verb input. We found this effect only for the morphological causal input from free play sessions. Acquiring causal verbs compared to non-causal ones might be more difficult for children. First, children have to pick semantic causality either for lexical or morphological verbs either from the context or from the morphology or from both. In that case, for causal verbs, children sometimes have a cue for causality (as in the case for morphological causal verbs) or no apparent cue (as in the case for lexical causal verbs). As our results indicated, morphological cues seem to relate to causal verb comprehension. Nevertheless, our verb comprehension task included mostly lexical causal verbs (20) compared to morphological causal verbs (4). This indicates that most of the verbs did not have transparent cues to derive causality information and thus a strong way to evaluate causal verbs comprehension. The present study was conducted in Turkish, a language with flexible word order and morphological causal suffixes. As early as 2.5 years old, Turkishlearning children can extract causal meaning from morphological cues (Ger, Stuber, Küntay, Goksun, Stoll \& Daum, 2021). Children who learn languages that have a strict word order are also faster at sentence processing compared to ones who learn languages that use flexible word order (Candan et al., 2012); however, word order is not the only cue (i.e., case markings, morphological cues) that is taken to account by Turkish-learning children (Göksun et al., 2008). In that sense, for those languages with flexible word order, children have to rely on both case marking as well as verb morphology which further increases the importance of the input (Candan et al., 2012, Ilgaz \& Hirsh-Pasek, 2012).

Another important finding is that only in the free play contexts we found a relation between early input and later child outcomes. However, for guided play context, none of the models were significant. Free play context might have created a more naturalistic environment for parent-child dyads. As children are more active and in the lead for free play context, they are more engaged with the play compared to guided play (Weisberg, Hirsh-Pasek \& Golinkoff, 2013a). Although the effectiveness of learning from guided play might overweigh free play in educational settings (Alfieri, Brooks, Aldrich \& Tenenbaum, 2010; Hirsh-Pasek, Golinkoff, Berk \& Singer, 2009; Lillard \& Else-Quest, 2006), free play is associated with positive outcomes for language and literacy development (e.g., Lillard, Lerner, Hopkins, Dore, Smith \& Palmquist, 2013; Neuman \& Roskos, 1992). Evidence suggests that child-centered approaches in free play with adult scaffolding are more effective in teaching compared to direct instruction (Stipek, Feiler, Daniels \& Milburn, 1995). Here, we provide further evidence for the role of free play in parents' use of causal 
morphological cues that can assist children's later causal vocabulary comprehension. Future research should highlight the importance of free play using different toys that might shed light on the type of play and contexts that specific toys elicit. Our results indicate that although more causal input is elicited in the guided play context, particularly in the form of lexical causal input, the free play context and morphological causatives predict causal verb understanding. These findings can also be discussed within the frequency-based explanations of language acquisition (Lieven, 2010). Based on this account, the "right level of granularity for measuring frequency" should be considered (p. 2554). That is, children's language production is not only influenced by the frequency of syntactic structures they are exposed to but also by the frequency with which they are exposed to particular structures in certain contexts. Thus, morphological input in the free play context might have greater input value to enhance causal verb understanding.

As a result of the longitudinal study in which we tested infants at three timepoints, we have a small sample size. Another limitation was that the toys chosen for both timepoints were not identical, and some differences stemming from play types may also be tied to the toys used. Each play session was 3 to 4 minutes, which might have limited the time for adapting to the contexts of play. Last, in these play sessions, children did not produce much language, and we experimentally tested verb comprehension at 3 years of age. Future research should also address causal verb production as well as comprehension of children in play contexts.

In conclusion, the present study investigated whether play contexts with different toys elicited differential causal language input and whether this early causal input was related to children's causal verb understanding. We demonstrated that causal language input might vary depending on play contexts. Importantly, the use of morphological causative input during free play sessions, but not lexical causative input, is related to children's later verb comprehension. Our results provide support for the link between parental causal input and causal verb comprehension in children, suggesting that learning causal verbs might be scaffolded by appropriate and more transparent causal input in certain play contexts.

Acknowledgments. This work was supported by TÜBİTAK (The Scientific and Technological Research Council of Turkey) 1001 Grant (\#114K342). Tilbe Göksun is also supported by James S. McDonnell Foundation Scholar Award (Grant no: 220020510). We thank everyone at Language and Cognition Lab in Koç University for their invaluable contributions to this project. We also thank members of Studies in Language and Bilingualism Lab (SiLab) Elif Nur Atalay, Ayşe Şüheda Örengül, and Pınar Karataş for their help in data transcription and coding. We are also grateful to the children and parents who participated in the study.

\section{References}

Aktan-Erciyes, A., \& Göksun, T. (2019). Early event understanding predicts later verb comprehension and motion event lexicalization. Developmental Psychology, 55(11), 2249-2262. https://doi.org/10.1037/ dev0000804.

Alfieri, L., Brooks, P. J., Aldrich, N. J., \& Tenenbaum, H. R. (2010). Does discovery-based instruction enhance learning? Journal of Educational Psychology, 103, 1-18, https://doi:10.1037/a0021017

Altınkamış, N. F., Kern, S., \& Sofu, H. (2014). When context matters more than language: Verb or noun in French and Turkish caregiver speech. First Language, 34, 537-550. https://doi.org/10.1177/ 0142723714560179

Berument, S. K., \& Güven, A. G. (2010). Turkish expressive and receptive language test: Receptive vocabulary sub-scale (TIFALDI-RT). Ankara, Turkey: Turkish Psychological Society. 
Blackwell, A. A. (2005). Acquiring the English adjective lexicon: relationships with input properties and adjectival semantic typology. Journal of Child Language, 32(3), 535-562. https://doi:10.1017/ S0305000907008641

Bornstein, M. H., Vibbert, M., Tal, J., \& O'Donnell, K. (1992). Toddler language and play in the second year: Stability, covariation and influences of parenting. First Language, 12(36), 323-338. https:// doi.org/10.1177/014272379201203607

Bowerman, M. (1974). Learning the structure of causative verbs: A study in the relationship of cognitive, semantic, and syntactic development. Papers and Reports on Child Language Development, 8, 142-178.

Brosnan, M. J. (1998). Spatial ability in children's play with Lego blocks. Perceptual and Motor Skills, 87(1), 19-28. https://doi.org/10.2466/pms.1998.87.1.19

Caldera, Y. M., Culp, A. M., O’Brien, M., Truglio, R. T., Alvarez, M., \& Huston, A. C. (1999). Children's play preferences, construction play with blocks, and visual-spatial skills: Are they related? International Journal of Behavioral Development, 23(4), 855-872. https://doi.org/10.1080/016502599383577

Candan, A., Küntay, A. C., Yeh, Y. C., Cheung, H., Wagner, L., \& Naigles, L. R. (2012). Language and age effects in children's processing of word order. Cognitive Development, 27(3), 205-221. https:// doi.org/10.1016/j.cogdev.2011.12.001

Cartmill, E., Pruden, S. M., Levine, S. C., Goldin-Meadow, S., \& Center, S. I. L. (2010). The role of parent gesture in children's spatial language development. In Proceedings of the 34th Annual Boston University Conference on Language Development (pp. 70-77). Somerville, MA: Cascadilla Press.

Comrie, B. (1989). Language Universals and Linguistic Typology, Basil Blackwell, Oxford.

Eason, S. H., \& Ramani, G. B. (2020). Parent-child math talk about fractions during formal learning and guided play activities. Child Development, 91(2), 546-562. https://doi.org/10.1111/cdev.13199

Evers-Vermeul, J. (2005). The development of Dutch connectives: Change and acquisition as windows on form-function relations. Unpublished Ph.D. dissertation, Utrecht University. Utrecht, LOT.

Evers-Vermeul, J., \& Sanders, T. (2001). 'Usage-based' versus 'Cognitive complexity'?: The acquisition order of Dutch connectives explained. Paper at the $7^{\text {th }}$ International Cognitive Linguistics Conference, Santa Barbara, CA, USA, July 22-27, 2001.

Ferrara, K., Hirsh-Pasek, K., Newcombe, N. S., Golinkoff, R. M., \& Lam, W. S. (2011). Block talk: Spatial language during block play. Mind, Brain, and Education, 5(3), 143-151. https://doi.org/10.1111/j.1751228X.2011.01122.x

Fisher, K. R., Hirsh-Pasek, K., Golinkoff, R. M., Singer, D., \& Berk, L. E. (2011). Playing around in school: Implications for learning and educational policy. In A. Pellegrini (Ed.), The Oxford handbook of the development of play (pp. 341-360). New York, NY: Oxford University Press.

Ger, E., Stuber, L., Küntay, A. C., Goksun, T., Stoll, S., \& Daum, M. M. (2021). Influence of causal language on causal understanding: A comparison between Swiss-German and Turkish. Journal of Experimental Child Psychology, 201, 105182. https://doi.org/10.1016/j.jecp.2021.105182.

Ginsburg, K. R. (2007). The importance of play in promoting healthy child development and maintaining strong parent-child bonds. Pediatrics, 119(1), 182-191. DOI: https://doi.org/10.1542/peds.2006-2697

Gleitman, L. (1990). The structural sources of verb meanings. Language Acquisition, 1(1), 3-55. https:// doi.org/10.1207/s15327817la0101_2

Göksel, A., \& Kerslake, C. (2005). Turkish: A comprehensive grammar. London, UK: Routledge.

Göksun, T., Küntay, A. C., \& Naigles, L. R. (2008). Turkish children use morphosyntactic bootstrapping in interpreting verb meaning. Journal of Child Language, 35(2), 291-312. https://doi:10.1017/ S0305000907008471

Göksun, T., Hirsh-Pasek, K., \& Golinkoff, R. M. (2010). Trading spaces: Carving up events for learning language. Perspectives on Psychological Science, 5(1), 33-42. https://doi.org/10.1177/1745691609356783

Gopnik, A., Glymour, C., Sobel, D. M., Schulz, L. E., Kushnir, T., \& Danks, D. (2004). A theory of causal learning in children: causal maps and Bayes nets. Psychological Review, 111(1), 1-31. https:// doi.org/10.1037/0033-295X.111.1.3

Hart, B., \& Risley, T. R. (1995). Meaningful differences in the everyday experience of young American children. Baltimore, MD: Paul H Brookes Publishing.

Hirsh-Pasek, K., Golinkoff, R. M., Berk, L. E., \& Singer, D. (2009). A mandate for playful learning in preschool: Presenting the evidence. New York: Oxford University Press.

Hoff, E. (2006). How social contexts support and shape language development. Developmental Review, 26(1), 55-88. https://doi.org/10.1016/j.dr.2005.11.002 
Ilgaz, H., \& Hirsh-Pasek, K. (2012). Commentary on "Language and age effects in children's processing of word order" by A. Candan, A. Küntay, Y. Yeh, H. Cheung, L. Wagner \& L.R. Naigles. Cognitive Development, 27, 222-226. https://doi.org/10.1016/j.cogdev.2012.04.001

Kanero, J., Hirsh-Pasek, K., \& Golinkoff, R. M. (2015). Can a microwave heat up coffee? How English-and Japanese-speaking children choose subjects in lexical causative sentences. Journal of Child Language, 15, 1-27. https://doi.org/10.1017/S0305000915000331

Ketrez, F. N. (1999). Early verbs and the acquisition of Turkish argument structure. Unpublished master's thesis, Bogaziçi University, Istanbul.

Kısa, Y. D., Aktan-Erciyes, A., Turan, E., \& Göksun, T. (2019). Parental use of spatial language and gestures in early childhood. British Journal of Developmental Psychology, 37(2), 149-167. https://doi.org/10.1111/ bjdp.12263

Konishi, H., Stahl, A. E., Golinkoff, R. M., \& Hirsh-Pasek, K. (2016). Individual differences in nonlinguistic event categorization predict later motion verb comprehension. Journal of Experimental Child Psychology, 151, 18-32. https://doi.org/10.1016/j.jecp.2016.03.012

Kornfilt, J. (1997). Turkish. London/NY: Routledge.

Landau, B., \& Gleitman, L. R. (1985). Language and experience: Evidence from the blind child. Cambridge, MA: Harvard University Press.

Levine, S. C., Ratliff, K. R., Huttenlocher, J., \& Cannon, J. (2012). Early puzzle play: a predictor of preschoolers' spatial transformation skill. Developmental Psychology, 48(2), 530-541. https:// doi.org/10.1037/a0025913

Lewis, C., \& Gregory, S. (1987). Parents' talk to their infants: The importance of context. First Language, 7 (21), 201-216. https://doi.org/10.1177/014272378700702104

Lieven, E. (2010). Input and first language acquisition: Evaluating the role of frequency. Lingua, 120(11), 2546-2556.

Lillard, A., \& Else-Quest, N. (2006). The early years: Evaluating Montessori education. Science, 313(5795), 1893-1894. https://doi.org/10.1126/science.1132362

Lillard, A. S., Lerner, M. D., Hopkins, E. J., Dore, R. A., Smith, E. D., \& Palmquist, C. M. (2013). The impact of pretend play on children's development: A review of the evidence. Psychological Bulletin, 139, $1-34$.

McCabe, A., \& Peterson, C. (1997). Meaningful "mistakes": The Systematicity of children's connectives in narrative discourse and the scial origins of this usage about the past. In J. Costermans \& M. Fayol (Eds.), Processing interclausal relationships: Studies in the production and comprehension of text, (pp.139-154). Mahwah, NJ: Erlbaum.

Michotte, A. (1963). The perception of causality. New York: Basic Books.

Muentener, P., \& Lakusta, L. (2011). The intention-to-CAUSE bias: Evidence from children's causal language. Cognition, 119(3), 341-355. https://doi.org/10.1016/j.cognition.2011.01.017

Naigles, L. R. (1996). The use of multiple frames in verb learning via syntactic bootstrapping. Cognition, 58(2), 221-251. https://doi.org/10.1016/0010-0277(95)00681-8

Naigles, L., Gleitman, H., \& Gleitman, L. (1993). Syntactic bootstrapping and verb acquisition. In E. Dromi (Ed.), Language and cognition: a developmental perspective. Norwood, NJ: Ablex.

Naigles, L. R., \& Hoff-Ginsberg, E. (1998). Why are some verbs learned before other verbs? Effects of input frequency and structure on children's early verb use. Journal of Child Language, 25(1), 95-120. https:// doi.org/10.1017/S0305000997003358

Neuman, S. B., \& Roskos, K. (1992). Literacy objects as cultural tools: Effects on children's literacy behaviors in play. Reading Research Quarterly, 27, 203-225. doi:10.2307/747792

O'Brien, M., \& Nagle, K. J. (1987). Parents' speech to toddlers: The effect of play context. Journal of Child Language, 14(2), 269-279. https://doi.org/10.1017/S0305000900012927

Piaget, J. (1954). The construction of reality in the child. New York: Basic Books.

Pruden, S. M., Levine, S. C., \& Huttenlocher, J. (2011). Children's spatial thinking: Does talk about the spatial world matter? Developmental Science, 14(6), 1417-1430. https://doi.org/10.1111/j.14677687.2011.01088.x

Saxe, R., \& Carey, S. (2006). The perception of causality in infancy. Acta Psychologica, 123(1-2), 144-165. https://doi.org/10.1016/j.actpsy.2006.05.005

Shibatani, M., \& Pardeshi, P. (2002). The causative continuum. In M. Shibatani (Ed.), The grammar of causation and interpersonal manipulation, (pp. 85-126). John Benjamins. 
Stipek, D., Feiler, R., Daniels, D., \& Milburn, S. (1995). Effects of different instructional approaches on young children's achievement and motivation. Child Development, 66(1), 209-223. https:// doi.org/10.1111/j.1467-8624.1995.tb00866.x

Tamis-LeMonda, C. S., \& Bornstein, M. H. (1991). Individual variation, correspondence, stability, and change in mother and toddler play. Infant Behavior and Development, 14(2), 143-162. https:// doi.org/10.1016/0163-6383(91)90002-A

Tamis-LeMonda, C. S., Bornstein, M. H., \& Baumwell, L. (2001). Maternal responsiveness and children's achievement of language milestones. Child Development, 72(3), 748-767. https://doi.org/10.1111/14678624.00313

Thippana, J., Elliott, L., Gehman, S., Libertus, K., \& Libertus, M. E. (2020). Parents' use of number talk with young children: Comparing methods, family factors, activity contexts, and relations to math skills. Early Childhood Research Quarterly, 53, 249-259. https://doi.org/10.1016/j.ecresq.2020.05.002

van Veen, R. (2011). The acquisition of causal connectives: The role of parental input and cognitive complexity. Utrecht University.

van Veen, R., Evers-Vermeul, J., Sanders, T. J. M., \& van den Bergh, H. (2013). The influence of input on connective acquisition: A growth curve analysis of English because and German weil. Journal of Child Language, 40(5), 1003-1031. https://doi.org/10.1017/S0305000912000451.

Weisberg, D. S., Hirsh-Pasek, K., \& Golinkoff, R. M. (2013a). Guided play: Where curricular goals meet a playful pedagogy. Mind, Brain, and Education, 7(2), 104-112. https://doi.org/10.1111/mbe.12015

Weisberg, D. S., Zosh, J. M., Hirsh-Pasek, K., \& Golinkoff, R. M. (2013b). Talking it up: play, language development, and the role of adult support. American Journal of Play, 6(1), 39-54.

Weisberg, D. S., Kittredge, A. K., Hirsh-Pasek, K., Golinkoff, R. M., \& Klahr, D. (2015). Making play work for education. Phi Delta Kappan, 96(8), 8-13. https://doi.org/10.1177/0031721715583955

Weisberg, D. S., Hirsh-Pasek, K., Golinkoff, R. M., Kittredge, A. K., \& Klahr, D. (2016). Guided play: Principles and practices. Current Directions in Psychological Science, 25(3), 177-182. https:// doi.org/10.1177/0963721416645512

Weizman, Z. O., \& Snow, C. E. (2001). Lexical output as related to children's vocabulary acquisition: Effects of sophisticated exposure and support for meaning. Developmental Psychology, 37(2), 265-278. https:// doi.org/10.1037/0012-1649.37.2.265

You, G., Daum, M., \& Stoll, S. (2020). Processing causatives in first language acquisition: A computational approach. In Proceedings of the 45th Annual Boston University Conference on Language Development, (pp. 818-828). Somerville, MA: Cascadilla Press.

Yu, Y., Shafto, P., Bonawitz, E., Yang, S. C., Golinkoff, R. M., Corriveau, K. H., Hirsh-Pasek, K., \& Xu, F. (2018). The theoretical and methodological opportunities afforded by guided play with young children. Frontiers in Psychology, 9, 1152-1163. https://doi.org/10.3389/fpsyg.2018.01152

Zosh, J. M., Hopkins, E. J., Jensen, H., Liu, C., Neale, D., Hirsh-Pasek, K., Solis, L. S., \& Whitebread, D. (2017). Learning through play: A review of the evidence. LEGO Foundation.

Cite this article: Aktan-Erciyes A., \& Göksun T. (2023). Early parental causal language input predicts children's later causal verb understanding. Journal of Child Language 50, 177-197. https://doi.org/10.1017/ S0305000921000805 